\title{
Smoke Water and Heat Shock Influence Germination of Shortgrass Prairie Species
}

\author{
Yi-Fang Chou, ${ }^{1}$ Robert D. Cox, ${ }^{2}$ and David B. Wester ${ }^{3}$ \\ Authors are ${ }^{1}$ Graduate Student and ${ }^{2}$ Assistant Professor, Department of Natural Resources Management, Texas Tech University, Lubbock, TX 79409, \\ USA; and ${ }^{3}$ Professor, Department of Animal, Rangeland, and Wildlife Sciences and Caesar Kleberg Wildlife Research Institute, Texas AßM University-
} Kingsville, Kingsville, TX 78363, USA.

\begin{abstract}
Smoke or heat from fire can act as a cue that affects seed germination. We examined germination responses of 10 plant species (six forbs, two shrubs, two grasses) native to the southern High Plains in the United States, to smoke, heat, and their interaction in a laboratory experiment. Smoke treatments were applied by soaking seeds in 1:5, 1:10, or 1:100 (v/v) Regen $2000^{\circledR}$ smoke solution for $20 \mathrm{~h}$. Heat treatments were applied by placing seeds in an oven at $50^{\circ} \mathrm{C}$ or $80^{\circ} \mathrm{C}$ for $5 \mathrm{~min}$. Nine species responded to smoke, heat, or both. Results showed that smoke can enhance, inhibit, or not affect seed germination. Germination capacities of Gutierrezia sarothrae (Pursh) Britton \& Rusby and Astragalus crassicarpus Nutt. were promoted by 1:5 and 1:100 dilutions of smoke water, respectively; Coreopsis tinctoria Nutt., G. sarothrae, Salvia reflexa Hornem., Digitaria ciliaris (Retz.) Koeler, and Panicum virgatum L. were inhibited by high and/or moderate concentrations of smoke water either in germination percentage or in mean germination time. Germination percentage of Solanum elaeagnifolium Cav. increased following an $80^{\circ} \mathrm{C}$ heat treatment. Interaction effects between smoke and heat on germination also were detected. Smoke and heat treatments might be useful as management tools for promoting or suppressing specific target species of shortgrass prairie communities in future habitat management.
\end{abstract}

\section{Resumen}

El ahumado o calor del fuego puede actúa como agente que afecta la germinación de semillas. En un experimento de laboratorio, examinamos la respuesta de diez especies nativas (seis hierbas, dos arbustos, y dos pastos) de las Planicies del Sur de los Estados Unidos al ahumado, calor y las interacciones. En los tratamientos de ahumado se remojaron semillas con la solución de ahumado Regen $2000^{\circledR}$ en 1:5, 1:10, o 1:100 (v/v) por 20 horas. Los tratamientos de calor se aplicaron poniendo semillas en un horno a $50^{\circ} \mathrm{C}$ o $80^{\circ} \mathrm{C}$ por 5 minutos. Nueve especies respondieron al ahumado, calor, o ambos. Los resultados mostraron que el ahumado podría mejorar, inhibir o no afectar la germinación. Las capacidades de germinación de la Gutierrezia sarothrae (Pursh) Britton \& Rusby y Astragalus crassicarpus Nutt. fueron estimuladas por la dilución de 1:5 y 1:100 ahumador agua, respectivamente; Coreopsis tinctoria Nutt., G. sarothrae, Salvia reflexa Hornem., Digitaria ciliaris (Retz.) Koeler, y Panicum virgatum $\mathrm{L}$. fueron inhibidas por alto y/o moderada concentración de ahumador agua en ambos porcetaje de germinación o en tiempo promedio de germinación. El porcentaje de germinación de Solanum elaeagnifolium Cav. aaumento después del tratamiento de calor a $80^{\circ} \mathrm{C}$. Se detectaron efectos de interacciones entre ahumado y calor en la germinación. Los tratamiento de ahumado y calor podrían ser útiles como herramientas de manejo para promover o suprimir especies claves especificas de las comnidades de las praderas de pastos cortos en futuros manejos de hábitat.

Key Words: fire cues, germination, heat, smoke, southern High Plains

\section{INTRODUCTION}

In areas with recurring fire, some plants have evolved adaptations such as thick bark, fire-resistant needles, or serotinous cones that require heat for seed dispersal (Dayamba et al. 2008). Seeds of certain plant species also can respond to products of fire such as heat, charred wood, and smoke by altering germination percentage or timing (van Staden et al. 2000; Thomas et al. 2007). The occurrence of fire removes previously existing plants from the site, releasing space and nutrients for establishment of new plants (Crosti et al. 2006); therefore, fire-related cues can promote germination of soilstored seeds (Keeley and Fotheringham 1998) at a time when establishment is most favorable. Certain species can even

Correspondence: Robert D. Cox, Dept of Natural Resources Management, Texas Tech University, Lubbock, TX 79409, USA. Email: robert.cox@ttu.edu

Manuscript received 3 June 2011; manuscript accepted 13 December 2011. germinate only when stimulated by fire-related cues (Keeley and Fotheringham 1998; Landis 2000).

Thus, smoke can be an important cue for germination of fireadapted species (van Staden et al. 2000). After plant-derived smoke was first reported to stimulate seed germination of fynbos species in South Africa (de Lange and Boucher 1990), smokegermination studies have been conducted in many parts of the world. In fire-prone Mediterranean-type ecosystems of western Australia, southern Australia, South Africa, and California, hundreds of species have been identified as responding to smoke (see Keeley and Fotheringham 2000 for a review). It is apparent that the effectiveness of smoke for stimulating germination occurs over a wide range of plant species, life forms, seed size, and seed morphology (Dixon and Roche 1995), and also can occur in species not typically associated with fire-prone areas, such as commercial maize (Zea mays L. cv. PAN6479) (Sparg et al. 2006), lettuce (Lactuca sativa L.) (Drewes et al. 1995), and several arable weed species (Adkins and Peters 2001). 
Numerous studies have been conducted to elucidate the mechanism of smoke-stimulated germination. It has been suggested that smoke can overcome seed dormancy by chemically scarifying the seed coat (Egerton-Warburton 1998), overcoming the light requirement for promoting germination (Drewes et al. 1995; Strydom et al. 1996; Plummer et al. 2001), and acting like gibberellic acid to trigger seed germination (Drewes et al. 1995). Rather than break primary dormancy directly, smoke also can stimulate germination after dormancy has been overcome by other means (Ooi et al. 2006). Flematti et al. (2004) identified the major active chemical compound triggering seed germination in smoke as butenolide, 3-methyl$2 H$-furo[2,3-c]pyran-2-one. It promotes both the percentage and rate of seed germination over a wide range of concentrations $\left(10^{-4} \mathrm{M}\right.$ to $\left.10^{-9} \mathrm{M}\right)$ (van Staden et al. 2004).

Another important fire cue that can break seed dormancy is heat. Exposing seeds to temperatures of $50^{\circ} \mathrm{C}$ to $150^{\circ} \mathrm{C}$ for $1 \mathrm{~min}$ to $60 \mathrm{~min}$ has promoted germination of seeds in many different families worldwide (Enright and Kintrup 2001; Thomas et al. 2003; Buhk and Hensen 2006; Bolin 2009; Tsuyuzaki and Miyoshi 2009). Heat acts as a scarification treatment and often breaks physically dormant seeds, including hard-seeded species in families such as Fabaceae and Anacardiaceae, making impermeable seed coats permeable to water (Auld and O'Connell 1991; Clarke et al. 2000; Enright and Kintrup 2001; Bolin 2009). This effect is not confined to hard-seeded species, however, because heat $\left(80^{\circ} \mathrm{C}\right.$ to $\left.100^{\circ} \mathrm{C}\right)$ also can promote germination of seeds with physiological rather than physical dormancy (Auld and O'Connell 1991; Read et al. 2000).

Fire was an important element in maintaining the structure and composition of Great Plains grasslands in the United States, where it also might have influenced the evolution of plant species (Hart and Hart 1997). The southern High Plains region, located in northwest Texas in the United States, therefore also might have species whose seeds respond to smoke or heat. However, there is no published information for smoke and heat-induced germination of plants native to this region. Few publications even consider this possibility; only Esque et al. (2010) suggest that fire might promote the germination of a widespread species that also is present in the southern High Plains region, namely Gutierrezia sarothrae (Pursh) Britton \& Rusby. They observed that seedling densities of this species seemed to be higher in postfire plots than in unburnt plots in Arizona. However, this result was not statistically analyzed due to low occurrence of seeds and seedlings (Esque et al. 2010).

To begin determining the extent of smoke and heat effects in shortgrass prairie species, we posed the following questions: 1 ) Do smoke and heat influence seed germination of species native to the shortgrass prairie in the southern High Plains region? 2) Is there an interaction effect between smoke and heat on the selected species? Answering these questions can provide information to assist in management, conservation, and restoration of the shortgrass prairie in this region.

\section{MATERIALS AND METHODS}

\section{Experimental Design}

We obtained fresh (i.e., less than 1 yr old; Panicum virgatum L. seeds were 2 yr old) seeds of 10 species native to the southern High
Plains region either by field collection or donation from commercial seed dealers. The southern High Plains are located in western Texas and eastern New Mexico in the United States. and are dominated by short bunchgrasses (Wester 2007). Seeds were stored at $5^{\circ} \mathrm{C}$ in glass jars until used for experiments. In order to identify as many smoke and heat responses as possible, we selected native species that belong to families already known to have species that respond to smoke or have dormant seeds, or both. Species selected belong to the families Asteraceae, Fabaceae, Lamiaceae, Poaceae, and Solanaceae (Table 1). Nomenclature follows the USDA PLANTS database (USDA-NRCS 2011).

To test the effects of smoke and heat shock on seed germination, we established a series of completely randomized fully, crossed factorial experiments with four concentrations of smoke water diluted in distilled water (control of $0,1: 100$, $1: 10$, and $1: 5$ ) and three levels of heat (no heat, $50^{\circ} \mathrm{C}$, and $80^{\circ} \mathrm{C}$ ). Each treatment was replicated four times, with 15-25 seeds for each replicate (depending on seed size). Replicates for the same treatment were conducted separately in time in order to avoid pseudoreplication (Morrison and Morris 2000).

Smoke applications were conducted using the commercially available aqueous smoke solution, Regen 2000, which is produced by Grayson Australia, a smoke-flavoring company in Australia, by burning eucalyptus wood and concentrating the smoke in aqueous solution (Wills and Read 2002). The aqueous smoke solution was diluted to desired concentrations with distilled water; the control treatment used only distilled water. Seeds of each species were soaked in smoke water/distilled water separately for $20 \mathrm{~h}$ at room temperature $\left(24^{\circ} \mathrm{C}\right)$. To apply heat shock, seeds were exposed to the desired temperature for $5 \mathrm{~min}$ in a preheated oven and then removed to room temperature for cooling. Seeds in the unheated control were not placed into the oven. When both smoke and heat-shock treatments were applied, heat shock was applied before smoke.

There were a total of 48 experimental units per species, or 480 experimental units overall (10 species $\times 12$ treatments $\times 4$ replications). After treatment, seeds were placed on moistened filter paper in $10 \mathrm{~cm} \times 10 \mathrm{~cm}$ germination boxes which were placed in a germination chamber programmed to provide a daily fluctuating temperature between $20-25^{\circ} \mathrm{C}$ (except for Solanum elaeagnifolium Cav., which was germinated at 20$30^{\circ} \mathrm{C}$ ) and an illumination cycle of $16 \mathrm{~h}$ and kept moist with distilled water. Germination was recorded daily; any seed with a radicle at least $1 \mathrm{~mm}$ long was considered to have germinated and was removed. Seeds that were obviously dead and moldy were removed (AOSA 2009). The experiment ran until all germination ceased (usually 20-25 d).

\section{Statistical Analysis}

Germination percentage (GP) and mean germination time (MGT) were calculated for each species and treatment as:

$$
\mathrm{GP}(\%)=\sum \mathrm{n}_{\mathrm{i}} / \mathrm{N} \cdot 100 \%
$$

$$
\operatorname{MGT}(\text { days })=\sum\left(\mathrm{t}_{\mathrm{i}} \cdot \mathrm{n}_{\mathrm{i}}\right) / \sum \mathrm{n}_{\mathrm{i}}
$$

where $\mathrm{n}_{\mathrm{i}}$ is the number of seeds germinating at each day, $\mathrm{N}$ is total number of seeds sown, $t_{i}$ is the number of days from the date of 
Table 1. Families, species, life forms, and sources of seeds tested in 2010 for germination response to smoke and heat. Nomenclature follows the USDA PLANTS database (USDA-NRCS 2011).

\begin{tabular}{|c|c|c|c|c|}
\hline Family & Species $^{1}$ & Life form & Source & References $^{2}$ \\
\hline \multirow[t]{2}{*}{ Asteraceae } & Coreopsis tinctoria Nutt. ${ }^{*}+$ & Forb & Vendor & Jefferson et al. 2008 \\
\hline & Gutierrezia sarothrae (Pursh) Britton \& Rusby & Shrub & Collected & - \\
\hline \multirow[t]{2}{*}{ Fabaceae } & Astragalus crassicarpus Nutt. ${ }^{*}$ & Forb & Vendor & Jefferson et al. 2008 \\
\hline & Prosopis glandulosa Torr. ${ }^{*} \mathrm{n}$ & Shrub/tree & Collected & Dayamba et al. 2008 \\
\hline \multirow[t]{3}{*}{ Lamiaceae } & Monarda citriodora Cerv. ex Lag. ${ }^{-}$ & Forb & Vendor & Jefferson et al. 2008 \\
\hline & Salvia azurea Michx. ex Lam. ${ }^{*}+$ & Forb & Vendor & Keeley and Fotheringham 1998 \\
\hline & Salvia reflexa Hornem. ${ }^{*}+$ & Forb & Collected & Keeley and Fotheringham 1998 \\
\hline \multirow[t]{2}{*}{ Poaceae } & Digitaria ciliaris (Retz.) Koeler ${ }^{\star}+n$ & Grass & Vendor & $\begin{array}{l}\text { Read and Bellairs 1999; Read et al. 2000; } \\
\text { Clarke and French 2005; Williams et al. } 2005\end{array}$ \\
\hline & Panicum virgatum $\mathrm{L}^{*}+$ & Grass & Vendor & $\begin{array}{l}\text { Read and Bellairs 1999; Read et al. 2000; } \\
\text { Clarke and French } 2005\end{array}$ \\
\hline Solanaceae & Solanum elaeagnifolium Cav. ${ }^{*}+-\mathrm{n}$ & Forb & Collected & $\begin{array}{l}\text { Read et al. 2000; Gomez-Gonzalez et al. 2008; } \\
\text { Commander et al. } 2009\end{array}$ \\
\hline
\end{tabular}

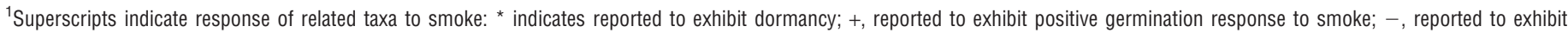
negative germination response to smoke; $\mathrm{n}$, reported to exhibit nonsignificant response.

${ }^{2}$ Published accounts of response of related taxa to smoke.

sowing until all germination ceased, and summation is over the number of days in a germination trial (Bewley and Black 1994).

A two-way ANOVA was used to test effects of smoke, heat, and their interaction on MGT. Before analysis, Levene's test (Levene 1960) was used to test for homogeneity of variances across treatments for each species; the Shapiro-Wilk test (Shapiro and Wilk 1965) was used to test normality of experimental errors within each treatment. When either assumption was not satisfied, F statistics were adjusted following Brown and Forsythe (1974). GP was analyzed with a logit link function using the GLIMMIX procedure in SAS (SAS Institute 2009). When there was an interaction between smoke and heat, we tested simple main effects and then interaction effects (Kirk 1995); a $t$ test was used for pairwise comparisons.

\section{RESULTS}

Both GP and MGT varied widely among species. For example, overall GP was about 7\% for Prosopis glandulosa Torr. and $81 \%$ for Panicum virgatum (Table 2). Likewise, Salvia reflexa Hornem. took just over $3 \mathrm{~d}$ to germinate, whereas $S$. elaeagnifolium took about $14 \mathrm{~d}$ (Table 2). Analysis of variance results for the laboratory experiment are summarized in Table 3.

Smoke-water treatment significantly influenced either GP or MGT in eight of the 10 species studied in the laboratory, although the direction of the effect was not consistent between and within species. Exposure to smoke water increased the GP of $G$. sarothrae at the 1:5-level treatment from 32\% (no smoke treatment) to $46 \%$ (Fig. 1a). Likewise, the GP of Astragalus crassicarpus Nutt. increased from 20\% (no smoke treatment) to $28 \%$ at the $1: 100$-level treatment (Fig. 1 b).

A negative influence of higher-concentration smoke-water treatments on GP was significant in two other species: Coreopsis tinctoria Nutt. and Digitaria ciliaris (Retz.) Koeler. Treatment with 1:5 concentration of smoke water decreased GP of C. tinctoria from $85 \%$ (no smoke treatment) to $45 \%$ (Fig. 1c), whereas GP of D. ciliaris was decreased from $80 \%$ (no smoke treatment) to $72 \%$ and $68 \%$ at $1: 10$ and $1: 5$ concentrations of smoke water, respectively (Fig. 1d). The effect of smoke also was significant in Monarda citriodora Cerv. ex Lag. but the difference was only significant between the $1: 100$ and the 1:5/1:10 treatment concentrations; no individual treatment was different from the control (data not shown).

Exposure to smoke significantly delayed the germination of G. sarothrae, C. tinctoria, D. ciliaris, S. reflexa, and $P$. virgatum (Figs. 2a-e). MGT of all of these species was increased by either 1:5 or 1:10-concentrations of smoke water or both. Of our 10 study species, only S. elaeagnifolium responded to heat. Heat shock at $80^{\circ} \mathrm{C}$ promoted GP of $S$. elaeagnifolium from $36 \%$ (untreated control) to $45 \%$, whereas heat shock at $50^{\circ} \mathrm{C}$ did not affect germination (data not shown).

Smoke water and heat interacted in their effects on GP, MGT or both for four species (A. crassicarpus, Salvia azurea Michx. ex Lam., S. reflexa, and $S$. elaeagnifolium) by generally inhibiting and/or delaying germination when high smoke concentrations were applied with moderate or high heat (Table 3 ). In each case, only certain combinations of smoke

Table 2. Average germination percentage (GP) and mean germination time (MGT) for shortgrass prairie species tested under laboratory conditions.

\begin{tabular}{llcc}
\hline Family & \multicolumn{1}{c}{ Species } & GP (\%) & MGT (days) \\
\hline Asteraceae & Coreopsis tinctoria & 74 & 5.62 \\
& Gutierrezia sarothrae & 35 & 9.13 \\
Fabaceae & Astragalus crassicarpus & 17 & 9.79 \\
& Prosopis glandulosa & 7 & 6.85 \\
Lamiaceae & Monarda citriodora & 49 & 4.44 \\
& Salvia azurea & 40 & 3.49 \\
& Salvia reflexa & 50 & 3.67 \\
Poaceae & Digitaria ciliaris & 74 & 6.03 \\
& Panicum virgatum & 81 & 4.72 \\
Solanaceae & Solanum elaeagnifolium & 38 & 14.01 \\
\hline
\end{tabular}


Table 3. Analysis of variance results ( $P$ values) for effects of smoke, heat, and their interaction on germination percentage (GP) and mean germination time (MGT) in the laboratory.

\begin{tabular}{|c|c|c|c|c|}
\hline Species & Index & Smoke & Heat & Smoke $\times$ heat \\
\hline \multirow[t]{2}{*}{ Coreopsis tinctoria } & GP & $<0.0001$ & 0.4575 & 0.1663 \\
\hline & MGT & $<0.0001$ & 0.4549 & 0.9256 \\
\hline \multirow[t]{2}{*}{ Gutierrezia sarothrae } & GP & 0.0009 & 0.4634 & 0.7080 \\
\hline & MGT & $<0.0001$ & 0.8816 & 0.9845 \\
\hline \multirow[t]{2}{*}{ Astragalus crassicarpus } & GP & 0.0139 & 0.4184 & 0.1222 \\
\hline & MGT & 0.0009 & 0.6958 & 0.0399 \\
\hline \multirow[t]{2}{*}{ Prosopis glandulosa } & GP & 0.3071 & 0.5427 & 0.1705 \\
\hline & MGT & 0.5128 & 0.8422 & 0.946 \\
\hline \multirow[t]{2}{*}{ Monarda citriodora } & GP & 0.0106 & 0.8482 & 0.8802 \\
\hline & MGT & 0.5440 & 0.5576 & 0.4776 \\
\hline \multirow[t]{2}{*}{ Salvia azurea } & GP & $<0.0001$ & 0.0003 & 0.0056 \\
\hline & MGT & 0.0002 & 0.9658 & 0.0397 \\
\hline \multirow[t]{2}{*}{ Salvia reflexa } & GP & $<0.0001$ & 0.9499 & 0.0371 \\
\hline & MGT & 0.0001 & 0.4177 & 0.6992 \\
\hline \multirow[t]{2}{*}{ Digitaria ciliaris } & GP & 0.0274 & 0.1245 & 0.3806 \\
\hline & MGT & $<0.0001$ & 0.1306 & 0.9968 \\
\hline \multirow[t]{2}{*}{ Panicum virgatum } & GP & 0.1973 & 0.4548 & 0.9368 \\
\hline & MGT & 0.0188 & 0.0506 & 0.3442 \\
\hline \multirow[t]{2}{*}{ Solanum elaeagnifolum } & GP & 0.6159 & 0.0116 & 0.5437 \\
\hline & MGT & 0.3370 & 0.3068 & 0.0431 \\
\hline
\end{tabular}
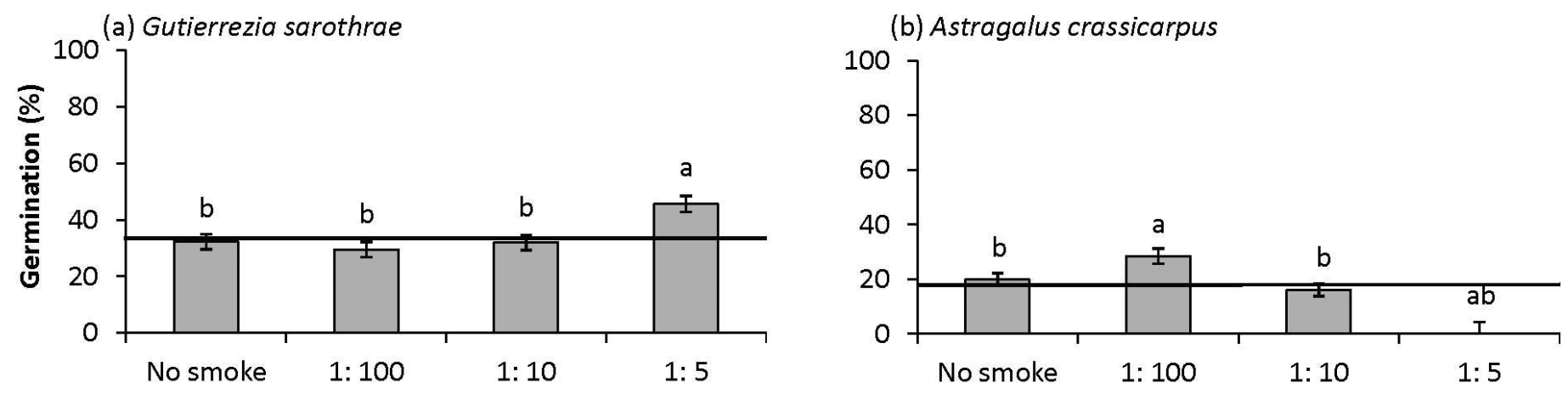

(c) Coreopsis tinctoria
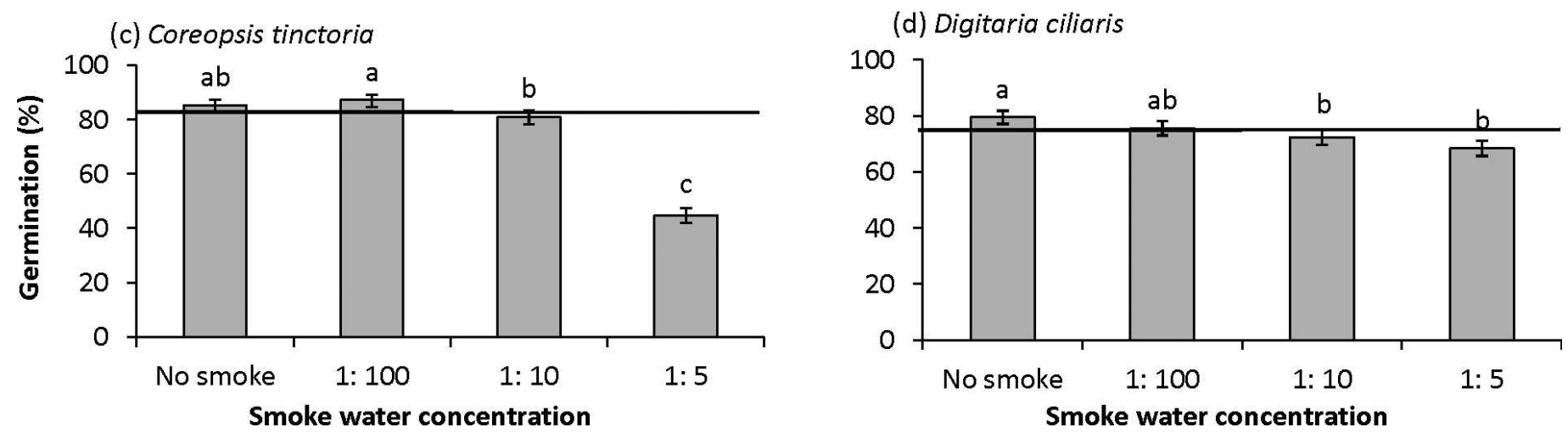

Figure 1. Main effect of smoke water on germination percentage (\%) of: a, Gutierrezia sarothrae; $\mathbf{b}$, Astragalus crassicarpus; c, Coreopsis tinctoria; d, Digitaria ciliaris (mean $\pm \mathrm{SE}$ ) in the laboratory. Within each species, means followed by the same letters are not significantly different $(P>0.05)$. Horizontal line represents average germination percentage of the control (neither heat nor smoke treated). 
(a) Gutierrezia sarothrae
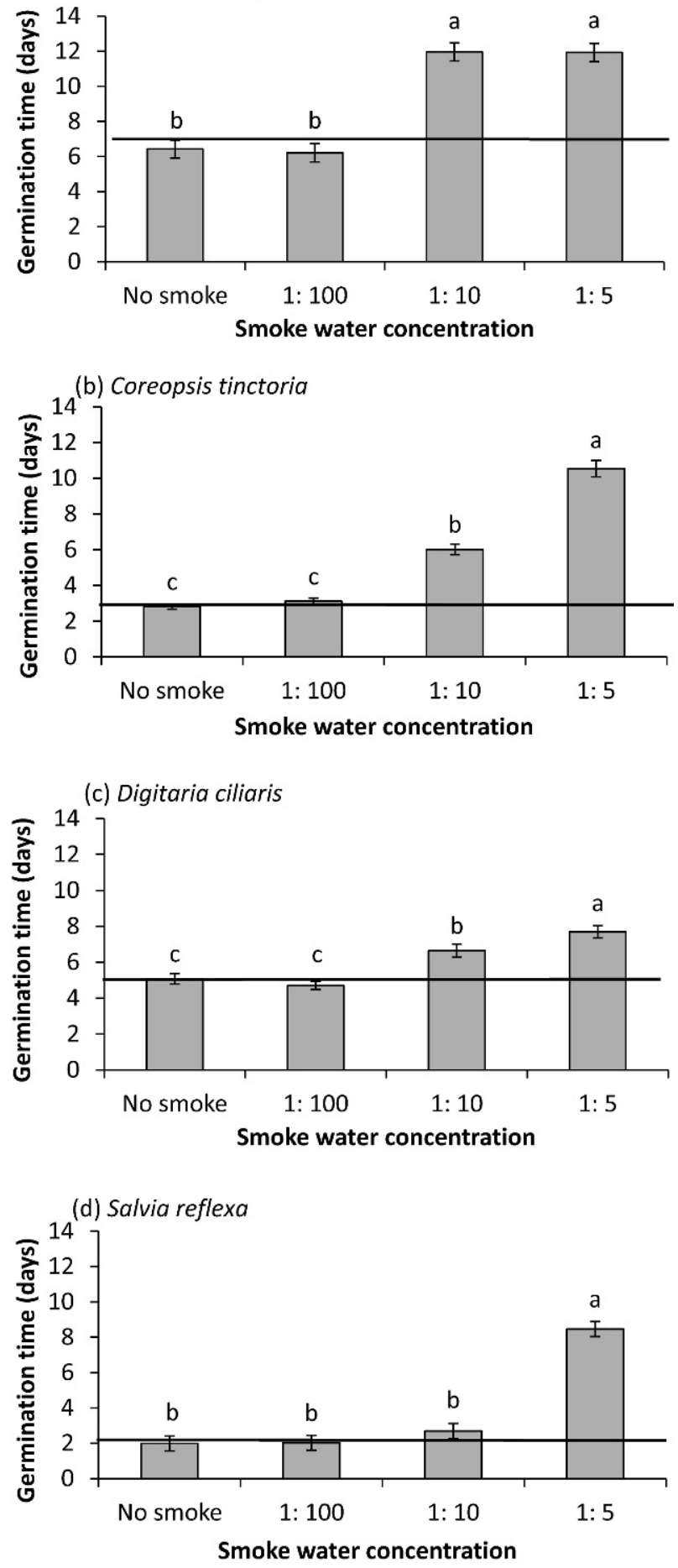

(e) Panicum virgatum

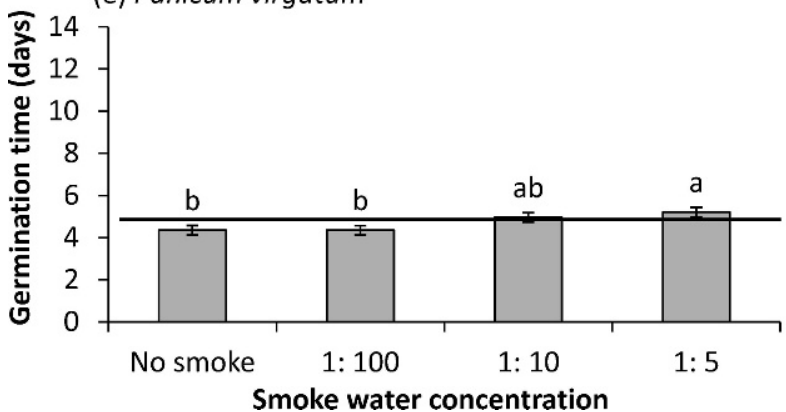

concentration and heat level affected GP or MGT. Smoke promoted GP of $S$. azurea only when the 1:100 concentration of smoke water was combined with $50^{\circ} \mathrm{C}$ heat, whereas moderate $(1: 10)$ and high (1:5) concentration smoke-water treatments inhibited the GP at all heat levels (Fig. 3a). For $S$. reflexa, combinations of high concentration smoke water (1:5) and heat $\left(50^{\circ} \mathrm{C}\right.$ or $\left.80^{\circ} \mathrm{C}\right)$ inhibited $\mathrm{GP}$, whereas moderate concentration smoke $(1: 10)$ and $50^{\circ} \mathrm{C}$ heat interacted to increase germination (Fig. 3b). Similarly, MGT of A. crassicarpus was influenced by both smoke and heat. For example, smoke water without heat tended to hasten germination, whereas high concentrations of smoke water (1:5) prolonged the germination significantly at both heat treatments (Fig. 4a). Likewise, the 1:10 level of smoke treatment delayed germination of $S$. azurea when combined with $50^{\circ} \mathrm{C}$ or $80^{\circ} \mathrm{C}$ heat, and the $1: 5$ treatment delayed germination at the $80^{\circ} \mathrm{C}$ treatment (Fig. 4b). Finally, MGT of S. elaeagnifolium displayed differences between smoke treatments within $50^{\circ}$ and $80^{\circ}$ heat treatments; no individual treatment differed from the control (Fig. 4c).

\section{DISCUSSION}

Smoke, heat, and their interaction affected germination of several species and potentially could be used as tools for shortgrass prairie management. Because the response to smoke and heat is very species- and concentration/temperature-specific in this study, management actions using these techniques should either focus on treating individual species as a seed treatment, or must consider how treatment of in situ soil seedbanks could influence the broader suite of species present. Nevertheless, the results of this study suggest specific management options. For example, G. sarothrae, a toxic subshrub of grazed rangelands (Ralphs and McDaniel 2011) could be managed by judicious application of smoke treatments used to stimulate germination and deplete the seedbank (Adkins and Peters 2001). Likewise, several of the tested species (C. tinctoria, S. reflexa, and D. ciliaris) could be preferentially disadvantaged by smoke treatment, if desired. Finally, these results can explain the responses that might be observed following either wild or prescribed fires.

In some cases, the responses we report are opposite from those reported elsewhere for related taxa (see Table 1). For example, Jefferson et al. (2008) found that Coreopsis lanceolata L. displayed increased germination when treated with aerosol smoke, but we found that germination of the related C. tinctoria was inhibited by high concentrations of smoke water, but was unresponsive at lower concentrations. Likewise, we found inhibition of germination in D. ciliaris, but other

Figure 2. Main effect of smoke water on the mean germination time (days) of: a, Gutierrezia sarothrae; b, Coreopsis tinctoria; c, Digitaria ciliaris; d, Salvia reflexa; e, Panicum virgatum (mean $\pm \mathrm{SE}$ ) in the laboratory. Within each species, means followed by the same letters are not significantly different $(P>0.05)$. Horizontal line represents average germination percentage of the control (neither heat nor smoke treated). 

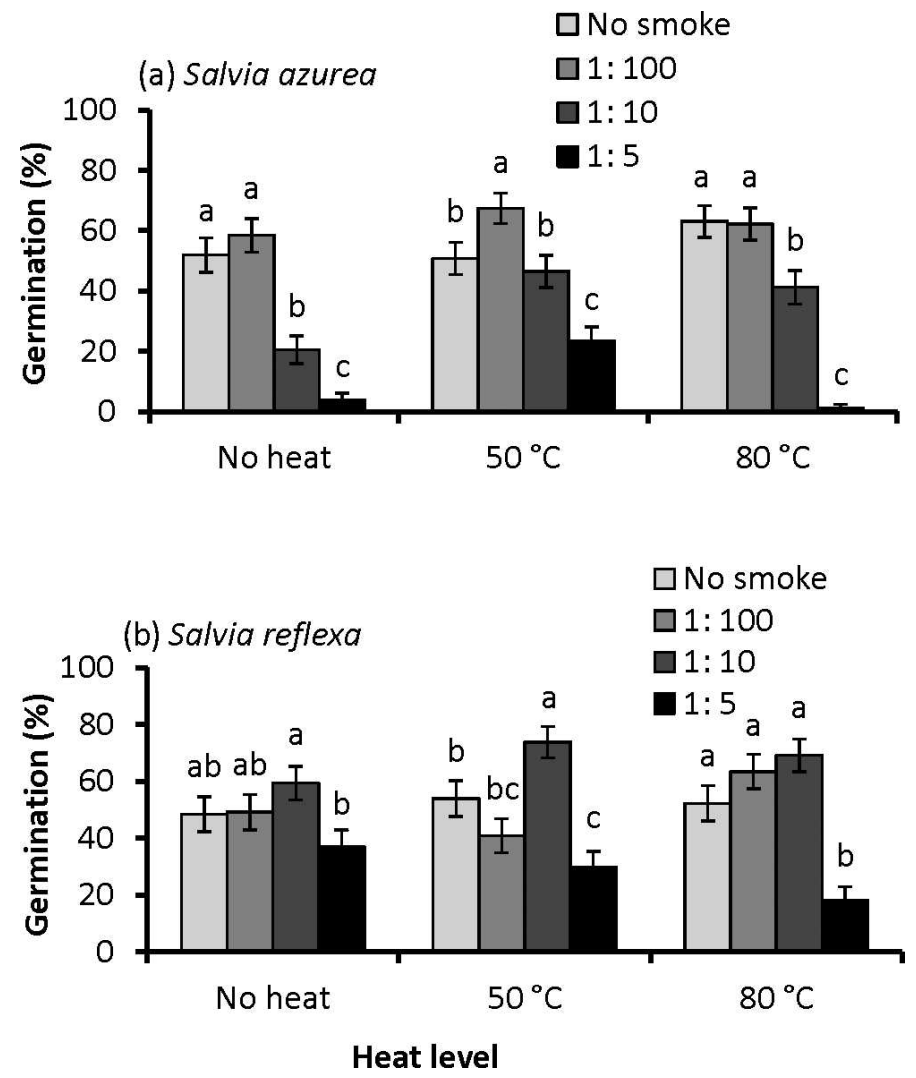

Figure 3. Interaction effects of smoke water and heat on GP of: a, Salvia azurea; b, Salvia reflexa (mean $\pm \mathrm{SE}$ ) in the laboratory. Within each species, means followed by the same letters are not significantly different $(P>0.05)$.

researchers, working with related taxa (Read and Bellairs 1999; Read et al. 2000; Clark and French 2005; Williams et al. 2005), found positive germination responses. In other cases, we found similar responses at one smoke-water concentration, but contrasting results at other concentrations (i.e., A. crassicarpus, S. azurea).

Two species (Coreopsis tinctoria and Digitaria ciliaris) displayed inhibition of GP at high (1:5) and medium (1:10) concentrations of smoke water. This is not surprising because high concentrations of smoke water (or long exposure to aerosol smoke) have been reported to reduce GP (Keeley and Fotheringham 1998; van Staden et al. 2000; Adkins and Peters 2001; Sparg et al. 2006). Likewise, MGT of several species (C. tinctoria, G. sarothrae, S. reflexa, D. ciliaris, and P. virgatum) was increased by high (1:5) and/or medium (1:10) concentrations of smoke water; other studies have also found that smoke can increase MGT in some species (Drewes et al. 1995; Daws et al. 2007). Inhibitors have been identified in smoke (Light et al. 2010) that do not appear to be lethal because the inhibition is reported to be reversible and the compound can be washed away, and seeds thereafter have an increased germination rate (Brown and van Staden 1997; Light et al. 2002; Sparg et al. 2005). In contrast, promotion of germination is irreversible, and cannot be stopped once it is initiated (Light et al. 2002). At high concentrations, it seems very likely that the influence of inhibitory substance(s) overrides promotive effects of the butenolide (Light et al. 2002).
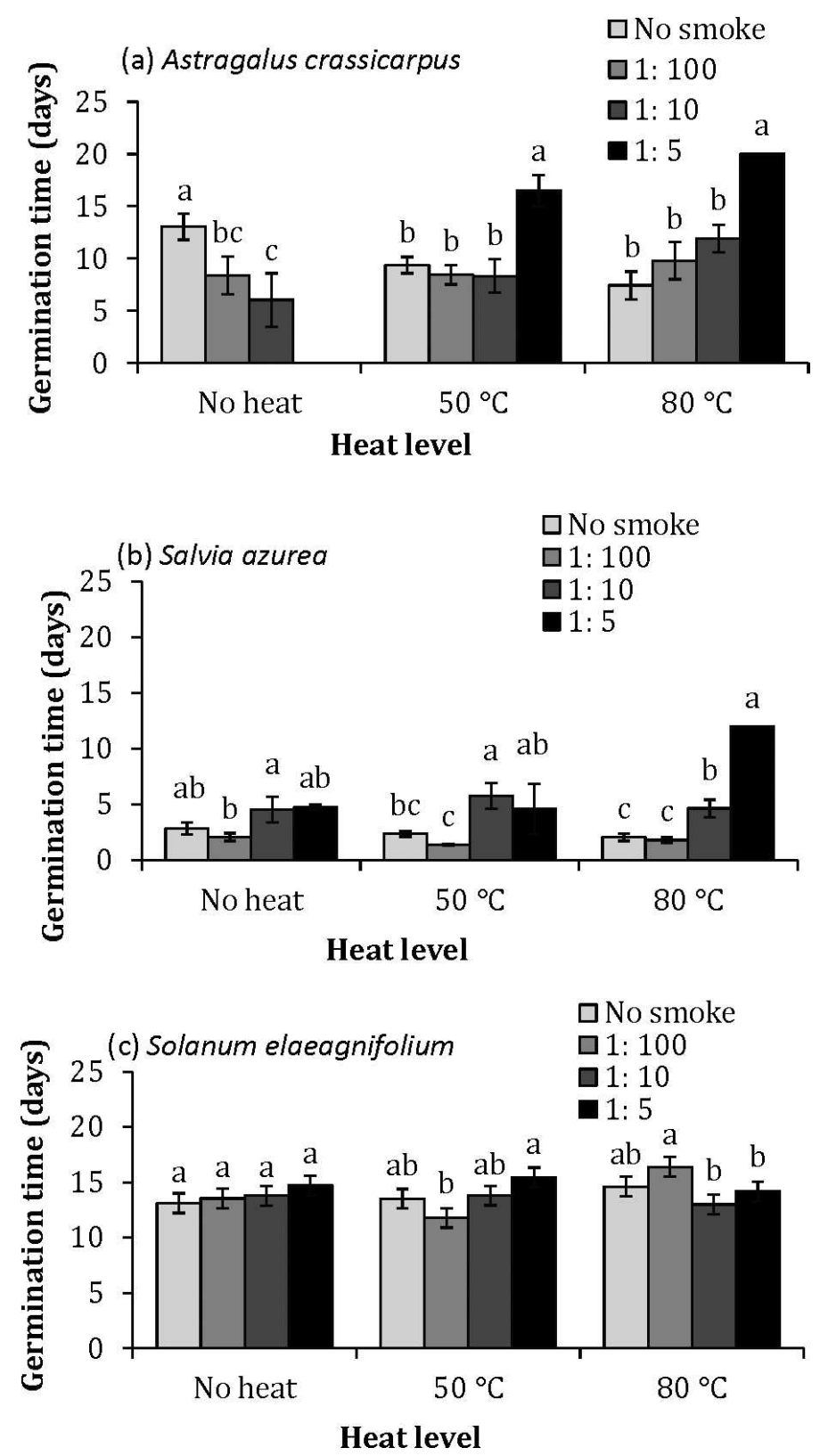

Figure 4. Interaction effects of smoke water and heat on MGT of: a, Astragalus crassicarpus; b, Salvia azurea; c, Solanum elaeagnifolium (mean $\pm \mathrm{SE}$ ) in the laboratory. Within each species, means followed by the same letters are not significantly different $(P>0.05)$. Any absent bars are due to insufficient germination of replicates at that treatment combination.

Efficient techniques for applying fire-related cues could be beneficial for management and restoration of shortgrass prairie. Although prescribed fire has been extensively studied in this region and commonly is used to control certain plant species or for managing vegetation (Parmenter 2008; Augustine and Milchunas 2009; Scheintaub et al. 2009), application of smoke and/or heat without fire could be a useful tool in some situations. Advantages of this approach include easy and precise control over concentration and/or temperature, and easier application in certain situations. Smoke already has been used for promoting preferred species (Baxter and van Staden 1994; Shebitz et al. 2009) and aiding in habitat rehabilitation 
(Read et al. 2000) in some areas. Of course, feasibility will largely depend on our understanding of how smoke and heat influence germination of a wide variety of species.

\section{IMPLICATIONS}

Although numerous studies have been conducted on smoke and/ or heat effects on germination percentage or rate (Roche et al. 1997b; Thomas et al. 2003; Dayamba et al. 2008), this study is among the first that we know of that investigates smoke and heat effects on shortgrass prairie species ex situ in the United States. More research is required before smoke and heat can be used effectively as management tools in the southern High Plains region, including testing these methods in the field, because field factors such as soil (Read and Bellairs 1999), seed aging (Roche et al. 1997b), and darkness (Tsuyuzaki and Miyoshi 2009) might interact with smoke and heat to affect the germination and produce different results. Effects of smoke water on soil-stored seed-bank germination, seedling density, seedling vigor, and overall species diversity also require investigation.

Nevertheless, smoke and heat treatments such as those tested here show promise for management and restoration activities in the southern High Plains of the United States. Possibilities for such treatments include aerosol smoke or smoke-water application to in situ soil seedbanks, treatment of seeds prior to sowing, and treatment of presowing seedbanks to stimulate germination of unwanted species, thereby depleting the seedbank (Roche et al. 1997a; Adkins and Peters 2001; Esque et al. 2010). Several of the species tested here (G. sarothrae, A. crassicarpus) generally are undesirable rangeland species, and yet they responded to smoke with increased germination percentage; these species conceivably might be managed in the field by judicious smoke application to in situ seedbanks with the goal of stimulating synchronized, massive germination for targeted control, while also depleting the seedbank. The majority of species tested, however, responded to smoke with decreased germination percentage or prolonging germination time, suggesting that rangeland managers should be careful when applying smoke treatments to avoid unwanted effects on species diversity.

\section{ACKNOWLEDGMENTS}

We sincerely express gratitude to P. E. Allen Farm Supply, Stock Seed Farms, Native American Seeds, and S\&S Seeds for providing high-quality seeds for our research.

\section{LITERATURE CITED}

Adkins, S. W., and N. C. B. Peters. 2001. Smoke derived from burnt vegetation stimulates germination of arable weeds. Seed Science Research 11:213-222.

AosA. 2009. Rules for testing seeds. Ithaca, NY, USA: Association of Official Seed Analysts. $228 \mathrm{p}$.

Augustine, D. J., and D. G. Milchunas. 2009. Vegetation responses to prescribed burning of grazed shortgrass steppe. Rangeland Ecology \& Management 62:89-97.

Auld, T. D., And M. A. O'Connell. 1991. Predicting patterns of post-fire germination in 35 eastern Australian Fabaceae. Austral Ecology 16:53-70.
Baxter, B. J. M., and J. van Staden. 1994. Plant-derived smoke: an effective seed pre-treatment. Plant Growth Regulation 14:279-282.

BewLEY, J. D., AND M. BLACK. 1994. Seeds: physiology of development and germination. New York, NY, USA: Springer. 445 p.

Bouin, J. F. 2009. Heat shock germination responses of three eastern North American temperate species. Castanea 74:160-167.

Brown, M. B., And A. B. Forsythe. 1974. The ANOVA and multiple comparisons for data with heterogeneous variances. Biometrics 30:719-724.

Brown, N. A. C., and J. van Staden. 1997. Smoke as a germination cue: a review. Plant Growth Regulation 22:115-124.

BuHK, C., And I. Hensen. 2006. "Fire seeders" during early post-fire succession and their quantitative importance in south-eastern Spain. Journal of Arid Environments 66:193-209.

Clarke, P. J., E. A. Davison, and L. Fulloon. 2000. Germination and dormancy of grassy woodland and forest species: effects of smoke, heat, darkness and cold. Australian Journal of Botany 48:687-700.

Clarke, S., and K. French. 2005. Germination response to heat and smoke of 22 Poaceae species from grassy woodlands. Australian Journal of Botany 53:445-454.

Commander, L. E., D. J. MerRitt, D. P. Rokich, and K. W. Dixon. 2009. Seed biology of Australian arid zone species: germination of 18 species used for rehabilitation. Journal of Arid Environments 73:617-625.

Crosti, R., P. G. Ladd, K. W. Dixon, and B. Piotto. 2006. Post-fire germination: the effect of smoke on seeds of selected species from the central Mediterranean basin. Forest Ecology and Management 221:306-312.

Daws, M. I., J. Davies, H. W. Pritchard, N. A. C. Brown, and J. van Staden. 2007. Butenolide from plant-derived smoke enhances germination and seedling growth of arable weed species. Plant Growth Regulation 51:73-82.

Dayamba, S. D., M. Tigabu, L. Sawadogo, and P. C. Oden. 2008. Seed germination of herbaceous and woody species of the Sudanian savanna-woodland in response to heat shock and smoke. Forest Ecology and Management 256:462-470.

de LAnge, J. H., AND C. Boucher. 1990. Autecological studies on Audouinia capitata (Bruniaceae). I. Plant-derived smoke as a seed germination cue. South African Journal of Botany 56:700-703.

Dixon, K. W., AND S. Roche. 1995. The role of combustion products (smoke) in stimulating ex situ and in situ germination of Western Australian plants. Proceedings of the International Plant Propagators Society 45:53-56.

Drewes, F. E., M. T. Smith, and J. van Staden. 1995. The effect of a plant-derived smoke extract on the germination of light-sensitive lettuce seed. Plant Growth Regulation 16:205-209.

Egerton-WarbuRton, L. 1998. A smoke-induced alteration of the sub-testa cuticle in seeds of the post-fire recruiter, Emmenanthe penduliflora Benth.(Hydrophyllaceae). Journal of Experimental Botany 49:1317-1327.

Enright, N. J., And A. Kintrup. 2001. Effects of smoke, heat and charred wood on the germination of dormant soil-stored seeds from a Eucalyptus baxteri heathy-woodland in Victoria, SE Australia. Austral Ecology 26:132-141.

Esque, T. C., J. A. Young, AND C. R. Tracy. 2010. Short-term effects of experimental fires on a Mojave Desert seed bank. Journal of Arid Environments 74:1302-1308.

Flematti, G. R., E. L. Ghisalberti, K. W. Dixon, and R. D. Trengove. 2004. A compound from smoke that promotes seed germination. Science 305:977.

Gomez-González, S., A. Sierra-Almeida, and L. A. Cavieres. 2008. Does plant-derived smoke affect seed germination in dominant woody species of the Mediterranean matorral of central Chile? Forest Ecology and Management 255:1510-1515.

HART, R. H., AND J. A. HART. 1997. Rangelands of the Great Plains before European settlement. Rangelands 19:4-11.

Jefferson, L. V., M. Pennacchio, K. Havens, B. Forsberg, D. Sollenberger, and J. Ault. 2008. Ex situ germination responses of midwestern USA prairie species to plant-derived smoke. American Midland Naturalist 159:251-256.

Keeley, J. E., and C. J. Fotheringham. 1998. Smoke-induced seed germination in California chaparral. Ecology 79:2320-2336.

KeEley, J. E., and C. J. Fotheringham. 2000. Role of fire in regeneration from seed. In: M. Fenner [ED.]. Seeds: the ecology of regeneration in plant communities. 2nd ed. Wallingford, UK: CAB International. p. 311-330. 
KIRK, R. 1995. Experimental design: procedures for behavorial sciences. 3rd ed. Pacific Grove, CA, USA: Brooks/Cole. 928 p.

LandIS, T. D. 2000. Where there's smoke... there's germination? Native Plants Journal 1:25-29.

LeVENE, H. 1960. Robust tests for equality of variances. In: I. Olkin, S. G. Ghurye, W. Hoeffding, W. G. Madow, and H. B. Mann [EDs.]. Contributions to probability and statistics: essays in honor of Harold Hotelling. Stanford, CA, USA: Stanford University Press. p. 278-292.

Light, M. E., B. V. Burger, D. Staerk, L. Kohout, and J. van Staden. 2010. Butenolides from plant-derived smoke: Natural plant-growth regulators with antagonistic actions on seed germination. Journal of Natural Products 73:267-269.

Light, M. E., M. J. Gardner, A. K. Jäger, and J. van Staden. 2002. Dual regulation of seed germination by smoke solutions. Plant Growth Regulation 37:135-141.

Morrison, D. A., And E. C. Morris. 2000. Pseudoreplication in experimental designs for the manipulation of seed germination treatments. Austral Ecology 25:292-296.

Ool, K., T. Auld, and R. Whelan. 2006. Dormancy and the fire-centric focus: germination of three Leucopogon species (Ericaceae) from south-eastern Australia. Annals of Botany 98:421-430.

Parmenter, R. R. 2008. Long-term effects of a summer fire on desert grassland plant demographics in New Mexico. Rangeland Ecology \& Management 61:156-168.

Plummer, J. A., A. D. Rogers, D. W. Turner, and D. T. Bell. 2001. Light, nitrogenous compounds, smoke and GA3 break dormancy and enhancegermination in the Australian everlasting daisy, Shoenia filifolia subsp. subulifolia. Seed Science and Technology 29:321-330.

Ralphs, M. H., and K. C. McDaniel. 2011. Broom snakeweed (Gutierrezia sarothrae): toxicology, ecology, control, and management. Invasive Plant Science and Management 4:125-132.

Read, T. R., and S. M. Bellairs. 1999. Smoke affects the germination of native grasses of New South Wales. Australian Journal of Botany 47:563-576.

Read, T. R., S. M. Bellairs, D. R. Mulligan, and D. Lamb. 2000. Smoke and heat effects on soil seed bank germination for the re-establishment of a native forest community in New South Wales. Austral Ecology 25:48-57.

Roche, S., K. W. Dixon, and J. S. Pate. 1997b. Seed ageing and smoke: partner cues in the amelioration of seed dormancy in selected Australian native species. Australian Journal of Botany 45:783-815.

Roche, S., J. M. KoCH, AND K. W. DIxon. 1997a. Smoke enhanced seed germination for mine rehabilitation in the southwest of Western Australia. Restoration Ecology 5:191-203.

SAS Institute. 2009. SAS/STAT 9.2 Users Guide. 2nd ed. Cary, NC, USA: SAS Institute. $7869 \mathrm{p}$.

Scheintaub, M. R., J. D. Derner, E. F. Kelly, and A. K. Knapp. 2009. Response of the shortgrass steppe plant community to fire. Journal of Arid Environments 73:1136-1143.
ShapIRo, S. S., AND M. B. WiLK. 1965. An analysis of variance test of normality (complete samples). Biometrika 52:591-611.

Shebitz, D. J., K. Ewing, and J. Gutierrez. 2009. Preliminary observations of using smoke-water to increase low-elevation beargrass Xerophyllum tenax germination. Native Plants Journal 10:13-20.

Sparg, S. G., M. G. Kulkarni, M. E. Light, and J. van Staden. 2005. Improving seedling vigour of indigenous medicinal plants with smoke. Bioresource Technology 96:1323-1330.

Sparg, S. G., M. G. Kulkarni, and J. van Staden. 2006. Aerosol smoke and smokewater stimulation of seedling vigor of a commercial maize cultivar. Crop Science 46:1336-1340.

Strydom, A., A. JäGer, and J. Staden. 1996. Effect of a plant-derived smoke extract, N6-benzyladenine and gibberellic acid on the thermodormancy of lettuce seeds. Plant Growth Regulation 19:97-100.

Thomas, P. B., E. C. Morris, and T. D. Auld. 2003. Interactive effects of heat shock and smoke on germination of nine species forming soil seed banks within the Sydney region. Austral Ecology 28:674-683.

Thomas, P. B., E. C. Morris, and T. D. Auld. 2007. Response surfaces for the combined effects of heat shock and smoke on germination of 16 species forming soil seed banks in south-east Australia. Austral Ecology 32:605616.

Tsuyuzaki, S., And C. Miroshi. 2009. Effects of smoke, heat, darkness and cold stratification on seed germination of 40 species in a cool temperate zone in northern Japan. Plant Biology 11:369-378.

USDA-NRCS. 2011. The PLANTS database. Available at: http://plants.usda.gov. Accessed 1 November 2011.

van Staden, J., N. A. C. Brown, A. K. Jager, and T. A. Johnson. 2000. Smoke as a germination cue. Plant Species Biology 15:167-178.

van Staden, J., A. K. Jager, M. E. Light, and B. V. Burger. 2004. Isolation of the major germination cue from plant-derived smoke. South African Journal of Botany 70:654-659.

Wester, D. B. 2007. The southern High Plains: a history of vegetation, 1540 to present. In: R. E. Sosebee, D. B. Wester, C. M. Britton, E. D. McArthur, and S. G. Kitchen [comps.]. 2007. Proceedings: Shrubland dynamics-fire and water; 10-12 August 2004; Lubbock, TX, USA. Fort Collins, CO, USA: USDA Forest Service Rocky Mountain Research Station. Proceedings RMRS-P-47. p. 24-47.

Williams, P. R., R. A. Congdon, A. C. Grice, and P. J. Clarke. 2005. Germinable soil seed banks in a tropical savanna: seasonal dynamics and effects of fire. Austral Ecology 30:79-90.

Wills, T. J., AND J. READ. 2002. Effects of heat and smoke on germination of soilstored seed in a south-eastern Australian sand heathland. Australian Journal of Botany 50:197-206. 